\title{
Effect of Natural Product Chemistry Laboratory Based on Sasambo Medicinal Plant (NPCL-SMP) on Metacognition Skills
}

\author{
Aliefman Hakim*, Abdul Wahab Jufri, Jamaluddin, Devi Ayu Septiani \\ University of Mataram, Mataram, Indonesia \\ Email: *Aliefmanhakim27@gmail.com
}

How to cite this paper: Hakim, A., Jufri, A. W., Jamaluddin, \& Septiani, D. A. (2021). Effect of Natural Product Chemistry Laboratory Based on Sasambo Medicinal Plant (NPCL-SMP) on Metacognition Skills. Creative Education, 12, 1840-1847.

https://doi.org/10.4236/ce.2021.128139

Received: June 6, 2021

Accepted: August 6, 2021

Published: August 9, 2021

Copyright $\odot 2021$ by author(s) and Scientific Research Publishing Inc. This work is licensed under the Creative Commons Attribution International License (CC BY 4.0).

http://creativecommons.org/licenses/by/4.0/

\begin{abstract}
This research aims to investigate effect of learning using Natural Product Chemistry Laboratory Based on Sasambo Medicinal Plant (NPCL-SMP) on students' metacognition skills. The research was conducted on sixth semester of 63 students of chemistry education program from one of the state universities in West Nusa Tenggara, Indonesia in 2020/2021. Students are divided into A class (experimental class) and B class (control class). The implementation was carried out according to the conditions of the COVID-19 outbreak. The laboratory implementation results showed an increase in the students' metacognition skills in the experimental class moderate and the control class as low. The experimental class students who received NPCL-SMP learning had better abilities in setting goals, making plans, and determining task completion strategies, compared to the control class who did conventional laboratory. We concluded that NPCL-SMP can improve the students' metacognition skills.
\end{abstract}

\section{Keywords}

Natural Product Chemistry Laboratory, Sasambo Medicinal Plant, Metacognition Skills

\section{Introduction}

Natural product chemistry has been used by humans in various aspects of life. In Indonesia, people have long known various medicinal plants that are usually made into herbal medicine which is a traditional medicine that has been used for generations in various generations. Data from the Indonesian Biodiversity Strategy and Action Plan (IBSAP), Indonesia is a country that has abundant biodiversity. The diversity of plants owned is a source of secondary metabolites which are widely known to have many benefits (Raharjo, 2013). 
Traditional medicine is widely used in the community for generations, so it is believed that its efficacy and safety. One of the areas in Indonesia that has many medicinal plants is West Nusa Tenggara whose people consist of the Sasak, Samawa, Mbojo (SASAMBO) tribes. Each of these tribes has a variety of traditional medicinal plants based on the hereditary beliefs of the local community. However, people do not know directly the content of traditional medicines that have been used so far. With the method of isolation and identification of compounds in Natural product Chemistry learning, it can be seen the benefits and uses of these medicinal plants (Liliasari, 2008).

Natural product chemistry studied secondary metabolites consisting of the structure, nature and origin of the biosynthesis of polyphenolic, terpenoids, steroids, flavonoids, alkaloids and several useful natural compounds as well as isolating secondary metabolites (Hakim et al., 2019). Atun (2014) explains that secondary metabolites can be separated from natural materials through an isolation process consisting of extraction, fractionation, purification and identification.

Natural product chemistry is a compulsory subject for students of the chemistry education study program. Natural product chemistry courses take place more effectively if using the labortory method (Hakim et al., 2015). Laboratory activities can facilitate students to connect different disciplines as a basis for designing small or large research, so as to develop creativity and student experience. Laboratory activities in natural product chemistry have the potential to develop students' metacognitive skills (Palendeng, 2003). According to Woolfolk (2010) and Marzano \& dan Kendall (2008), metacognitive skills are skills that are used to control cognitive activities and ensure that cognitive goals have been achieved. Metacognition is based on a person's ability to consciously plan, monitor and evaluate a learning process that is being worked on (Mega et al., 2018). The indicators of metacognitive skills according to Schraw \& Dennison (1994) are 1) declarative knowledge, 2) procedural knowledge, 3) conditional knowledge, 4) planning, 5) information management strategies, 6) monitoring, 7) evaluation, and 8) revising. In natural product chemistry laboratory activities, students are given the opportunity to organize and design their own as well as solve problems in practicum activities for isolating secondary metabolites from medicinal plants of the SASAMBO tribe, starting from the process of laboratory preparation to laboratory implementation. In this laboratory, students were exposed to skills as extraction, fractionation, purification, and structural elucidation of secondary metabolites. These various activities were able to improve students' Metacognition skills. Metacognition skills are needed by students to adjust and manage their thinking strategies in solving a problem and thinking about a particular goal.

\section{Methodology}

The type of research carried out is quasi-experimental (Sugiyono, 2014). The research design used was a nonequivalent control group design pretest-posttest. 
The design in this study was the experimental class and the control class were given treatment and a final test. The experimental class was given the application of the Natural Product Chemistry Laboratory Based on Sasambo Medicinal Plant (NPCL-SMP), while the control class was given the application of the conventional Natural Product Chemistry laboratory. Sampling in this study used a purposive method. Participants in this study consisted of 63 third year students (teacher preparation) from the chemistry education department at one of the state universities in West Nusa Tenggara, Indonesia. Participants consist of A class (33 students) and B class (30 students). The initial metacognition skills of the two classes are equivalent. A Class as the experimental class and class B as the control class. These two samples were taken by purposive sampling technique (Sugiyono, 2014). The implementation was carried out according to the conditions of the COVID-19 outbreak. The presentation of proposals and presentations of the results of the laboratory activities was done online. Laboratory activities were carried out alternately that only one group was allowed to enter the laboratory each time.

\section{Data Collection and Data Analysis Techniques}

In this study, data collection used tests and non-tests. The test instrument was used to measure metacognitive ability with 9 valid and reliable description test items, developed from three indicators of metacognitive ability: 1) goal setting skills, 2) process monitoring, and 3) monitoring accuracy.

The non-test instruments used were in the form of a perception questionnaire sheet on metacognitive abilities and an NPCL-SMP learning observation sheet. Questionnaire perceptions of students' metacognitive skills were measured using the Metacognitive Skills Inventory (MSI) which was adapted from MAI (Schraw \& Dennison, 1994) and SEMLI-S (Thomas et al., 2008). This questionnaire consists of 34 statement items which are divided into skills in planning, monitoring, evaluation, and revising.

The data obtained were processed by several stages of testing in the form of normality test, homogeneity of variance test, hypothesis testing, and analysis of metacognition skills. Test the hypothesis in this study using Gain t-test. Gain The t-test was performed after the data were analyzed with normality and homogeneity tests, while the normalized Gain test was used to determine the increase in metacognitive skills.

\section{Results and Discussion}

The Natural Product Chemistry Laboratory Based on Sasambo Medicinal Plant (NPCL-SMP) is one of the practical applications using laboratory materials derived from medicinal plants from the Sasambo tribe (Sasak, Samawa, Mbojo). In addition, the application of this practicum will also link the cultural phenomena of the Sasambo community with science, especially the natural product chemistry. The laboratory activities create a more meaningful learning atmosphere and 
students' understanding of a material will also be better because the learning material is associated with the habits or culture of the community.

In the focus of this research observation is the effect of the Natural Product Chemistry Laboratory Based on Sasambo Medicinal Plant (NPCL-SMP) on students' metacognitive skills. The effect of NPCL-SMP can be seen from the increase in the value of the initial test (pretest) to the final test (posttest) in the cognitive domain. The implementation of learning is carried out in each class as many as 12 meetings including pretest-posttest activities. In the control class, they learn through conventional practicum activities where students only follow the steps of the experimental activity according to the practicum instructions, while the experimental class learns with the NPCL-SMP stages.

The results of the initial data analysis refer to the students' pretest scores, so the homogeneity test is carried out. From the calculation results obtained homogeneous class $\mathrm{A}$ and $\mathrm{B}$. The results of the homogeneity test of the initial data obtained were class A and class B, with Fcount $<$ Ftable $(1.24<1.71)$, so it could be considered that the control and experimental classes were homogeneous.

The normality test in this study uses the chi-square formula. Based on the calculation results, the pretest value in the experimental class was 6.01 and the control class was 9.39. The value ( $\chi^{2}$ count) is then consulted with the price $\left(\chi^{2}\right.$ table) at a significant level of $5 \%$, which is 11.07 with $\mathrm{dk}=5$, so that 2 count $<$ 2 table which means that the data from the pretest results in both classes are normally distributed (Sugiyono, 2014). In the posttest value, the value ( $\chi^{2}$ count) in the experimental class was 2.85 and the control class was 11.86 . The value $\left(\chi^{2}\right.$ count) was then consulted with the price ( $\chi^{2}$ table) at a significant level of $5 \%$, namely 12.59 with $\mathrm{dk}=6$, so that 2 count $<\chi^{2}$ table which means that the data from the pretest results in both classes are normally distributed (Sugiyono, 2014).

The homogeneity of variance test in this study uses the F-test formula. Based on calculations using posttest value data, the Fcount value is 1.29. The price of Fcount is consulted on Ftable with a significant level of $5 \%$ of 1.69 so that the price of Fcount $<$ Ftable $(1.29<1.69)$ then the variance of the two data is said to be homogeneous (Sugiyono, 2016).

To prove the hypothesis in this study, the metacognitive skills cognitive result data was processed using the Gain t-test formula because in this study there was a control group and an experimental group, both of which were given pretest and posttest. The difference of average value in this study used t-test (Arikunto, 2010). Based on the calculation results, the value of $t$ count (3.10) $>t$ table (1.67) at a significant level of $5 \%$ showed that statistically the application of the Natural Product Chemistry Laboratory based on Medicinal Plants Sasambo has a positive effect on students' metacognitive skills.

Students' metacognitive skills were measured before and after lectures with 9 essay test items. Furthermore, the data were analyzed by calculating the normalized test gain to determine the average and percentage changes in students' metacognitive skills scores. The research data related to the average score and the 
percentage change in the pretest-posttest scores of students' metacognitive skills in each class are shown in Figure 1.

Based on Figure 1, it showed a graph with an increase in the average value in the experimental class which is quite significant (moderate) and the control class is classified as a low increase. This average value is obtained from the average score for all items on the metacognitive ability indicators: 1) goal setting skills, 2) process monitoring and 3) monitoring accuracy. In addition to being measured by the test instrument for the description of students' metacognitive skills, it was also measured using a metacognitive skill perception questionnaire based on the Metacognitive Skill Inventory (MSI). Students' metacognitive skills were measured before and after lectures. Furthermore, the data were analyzed with descriptive statistics to determine the average and percentage change in students' metacognitive skills scores. The research data related to the average score and the percentage change in the pretest-posttest scores of students' metacognitive skills in each class are shown in Figure 2.

Based on the graph in Figure 2 shows the increase in the average value in the experimental class is quite significant (moderate) and the control class is classified as a low increase. This average value was obtained from the average score for all questionnaire items on the planning, monitoring, evaluation, and revising indicators which were adapted from MAI (Schraw \& Dennison, 1994) and

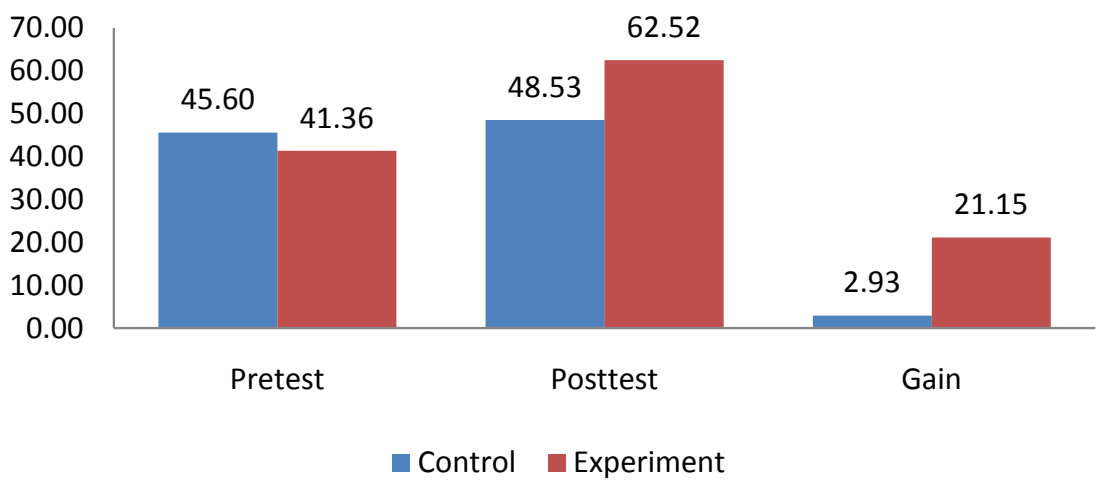

Figure 1. Metacognitive skills test average.

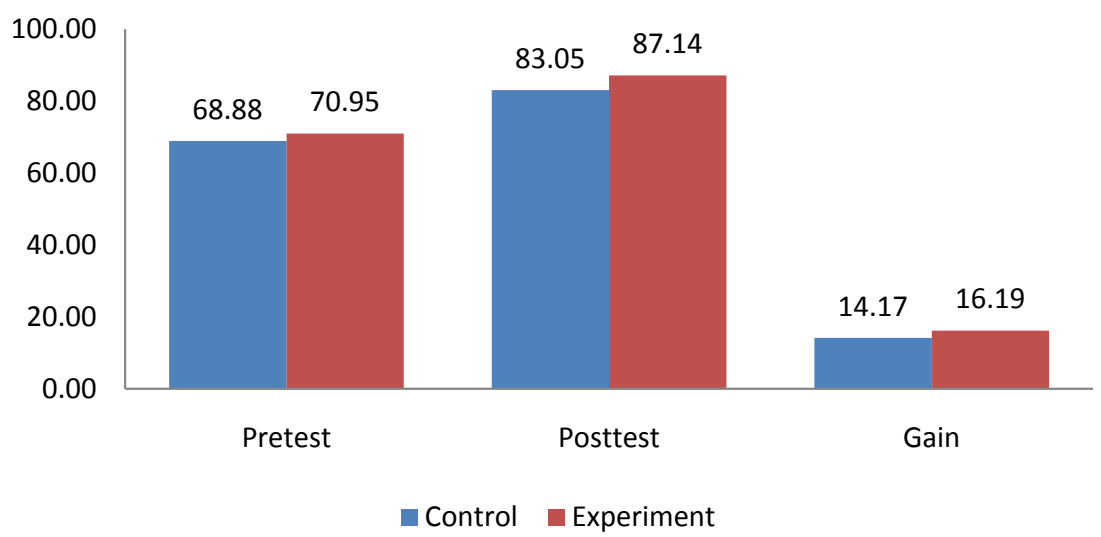

Figure 2. MSI questionnaire average score. 
SEMLI-S (Thomas et al., 2008). Based on the results of the analysis, it can be seen that the experimental class students who received NPCL-SMP learning had better abilities in setting goals, making plans, and determining task completion strategies, compared to the control class who did conventional laboratory.

The first stage of the Natural Product Chemistry Laboratory Based on Sasambo Medicinal Plant (NPCL-SMP) is the pre-practicum stage and the orientation of the practicum sample, namely the stage in directing and providing essential questions to students about plants in the surrounding environment that have the potential to serve as drugs by the public, especially Sasambo. This is done to stimulate curiosity and encourage students to reason and determine their learning goals. In the next stage, students make a project implementation plan and project implementation schedule. This activity trains students to determine the theme, purpose of the experiment, find relevant information, tools and materials needed, experimental procedures and division of tasks among group members. The last stage, students present the results of their practicum in front of the class. In the discussion process in the presentation activity, students exchange information and opinions regarding the results of their practicum whether it is in accordance with the material and discourse provided by the researcher and can solve the problems given. This means that all students are actively involved in the group. In the presentation activity, the researcher also carried out an assessment process through observation sheets assisted by several observers, which in this observation sheet contained indicators of metacognitive skills that were assessed through attitudes in conducting presentation activities. Of course, this observation sheet aims to support research data to see students' metacognitive skills.

The control class conducts learning through conventional practicum activities where students only follow the steps of the experimental activity in accordance with the practical instructions provided by the lecturer. This does not facilitate the development of students' metacognitive skills in setting goals, making activity plans and determining task completion strategies. Students are able to complete practicum assignments but their metacognitive skills are not trained because they are not involved in the planning process of the practicum activities.

In the experimental class that applies NPCL-SMP, it presents a fun and meaningful group learning experience. Each student can speak and argue and exert all their abilities in understanding the material provided and raise the theme of practicum by linking medicinal plants to the Sasambo community, so that their learning outcomes increase and have a positive effect on students' metacognitive skills. This is in accordance with the opinion of Amir \& Wardana (2018) that one's metacognitive ability will be seen when contextual problem-based learning is applied to show students' awareness in solving problems starting from planning (planning), monitoring (monitoring), and evaluating (evaluation). Students' metacognitive abilities can help strengthen a thorough understanding of problems and their solutions with logical arguments, so that students' self-confidence will grow when solving problems (Barbacena \& Sy, 2015). The role of the re- 
searcher is as a motivator and facilitator who controls students during the practicum process and presentation activities. Metacognition skills can help students become independent learners and can control their own progress.

\section{Conclusion}

The results obtained indicate that the Natural Product Chemistry Laboratory Based on Sasambo Medicinal Plant (NPCL-SMP) can have a positive influence on the metacognitive skills of 6th semester students of students (teacher preparation) from the chemistry education department at one of the state universities in West Nusa Tenggara, Indonesia.

\section{Conflicts of Interest}

The authors declare no conflicts of interest regarding the publication of this paper.

\section{References}

Amir, M. F., \& Wardana, M. D. K. (2018). Masalah Kontekstual Untuk Meningkatkan kompetensi. Badan Nasional Standar, 2, 117-128.

Arikunto, S. (2010). Prosedur Penelitian (Suatu Pendekatan Praktik). Rineka Cipta.

Atun, S. (2014). Metode Isolasi dan Identifikasi Struktur Senyawa Organik Kimia Bahan Alam. Jurnal Konservasi Cagar Budaya Borobudur, 8, 53-61. https://doi.org/10.33374/jurnalkonservasicagarbudaya.v8i2.132

Barbacena, L. B., \& Sy, N. R. (2015). Metacognitive Model in Mathematical Problem Solving. BU Faculty E-Journal, 12, 16-22.

Hakim, A., Jufri, A. W., Jamaluddin, J., Andayani, Y., Rahayuan, B. D., \& Supriadi, S. (2019). Promoting Students' Metacognition in Natural Product Chemistry Course through Mini Project Laboratory. Open Access Library Journal, 6, 1-8.

Hakim, H., Liliasari, L., Kadarohman, A., Syah, M. Y., \& Musthapa, I. (2015). Pembelajaran Kimia Bahan Alam Inovatif Melalui Praktikum. Prosiding Seminar Nasional "Arah Pendidikan MIPA Masa Depan; Antara Harapan dan Kenyataan”, 1, 1-9.

Liliasari (2008). Peningkatan kualitas pendidikan kimia dari pemahaman konsep kimia menjadi berpikir kimia. Makalah Seminar UNY, Universitas Pendidikan Indonesia.

Marzano, R. J., \& dan Kendall, J. S. (2008). Designing \& Assessing Educational Objectives. The American Association of School Administration.

Mega, W. W., Mulyani, S., \& dan Utomo, S. B. (2018). Pengaruh Model Pembelajaran Problem Solving dan Learning Cycle 5E terhadap Prestasi Belajar ditinjau dari Kemampuan Metakognisi Siswa. Jurnal Penelitian Pendidikan, 21, 186-202. https://doi.org/10.20961/paedagogia.v21i2.23494

Palendeng (2003). Strategi Pembelajaran Aktif. Rineka Cipta.

Raharjo, T. (2013). Kimia Bahan Alam. Pustaka Belajar.

Schraw, G., \& Dennison, R. S. (1994). Assesing Metacognitive A wareness: Contemporry Educational Psichology. University of Nebraska of Lincoln.

Sugiyono (2014). Penelitian Pendidikan Pendekatan Kuantitatif, Kualitatif dan $R \& D$. Alfabeta.

Sugiyono (2016). Metode Penelitian Kombinasi (Mixed Methods). Alfabeta. 
A. Hakim et al.

Thomas, G., Anderson, D., \& Nashon, S. (2008). Development of an Instrument Designed to Investigate Elements of Science Students' Metacognition, Self-Efficacy and Learning Processes: The SEMLI-S. International Journal of Science Education, 30, 1701-1724. https://doi.org/10.1080/09500690701482493

Woolfolk, A. (2010). Educational Psychology. Pearson Education International. 